\title{
Hospital Pharmacological Treatment of Acute Myocardial Infarction with st Supra: Sus x Private
}

Jussiely Cunha Oliveira ${ }^{1,2 *}$, Nathan Cunha de Jesus ${ }^{3}$, Jeferson Cunha Oliveira ${ }^{1}$, Ticiane Clair Remacre Munareto Lima ${ }^{1,4}$, Ikaro Daniel de Carvalho Barreto $^{1,5}$, Ingrid Melo Santos ${ }^{6}$, Fernanda G. de M. Soares Pinheiro ${ }^{2}$, José Augusto Soares Barreto-Filho ${ }^{1,3,7,8}$.

${ }^{1}$ Programa de Pós-Graduação em Ciências da Saúde, Universidade Federal de Sergipe, Aracaju, Sergipe, Brasil.

${ }^{2}$ Núcleo de Pós-graduação em Enfermagem da Universidade Federal de Sergipe,1 Aracaju, SE - Brasil

${ }^{3}$ Departamento de Medicina, Universidade Federal de Sergipe, Aracaju, Sergipe, Brasil.

${ }^{4}$ Departamento de Nutrição da Universidade Tiradentes, 7 Aracaju, SE - Brasil

${ }^{5}$ Programa de Pós-Graduação em Biometria e Estatística Aplicada, Universidade Federal Rural de Pernambuco, Recife, Pernambuco, Brasil.

${ }^{6}$ Departamento de Fármacia da Universidade Tiradentes, 7 Aracaju, SE - Brasil

${ }^{7}$ Clínica e Hospital São Lucas, Rede D'or, Aracaju, Sergipe, Brasil.

${ }^{8}$ Setor de Cardiologia, Hospital Universitário, Universidade Federal de Sergipe, Aracaju, Sergipe, Brasil.

*Corresponding Author: Jussiely Cunha Oliveira, Universidade Federal de Sergipe - Cidade Univ. Prof. José Aloísio de Campos Av. Marechal Rondon, s/n. CEP 49100-000, Jd. Rosa Elze, São Cristóvão, SE - Brasil.

Received Date: July 28, 2021; Accepted Date: August 24, 2021; Published Date: Augusł 30, 2021

Citation: Jussiely C. Oliveira, de Jesus NC., Jeferson C. Oliveira., Munareto Lima TCR., Carvalho Barreto IDD., et al. (2021) Hospital Pharmacological Treatment of Acute Myocardial Infarction with st Supra: Sus x Private.. J. Clinical Cardiology and Cardiovascular Interventions, 4(16); DOI:10.31579/2641-0419/205

Copyright: (C) 2021 Jussiely Cunha Oliveira, This is an open-access article distributed under the terms of the Creative Commons Attribution License, which permits unrestricted use, distribution, and reproduction in any medium, provided the original author and source are credited.

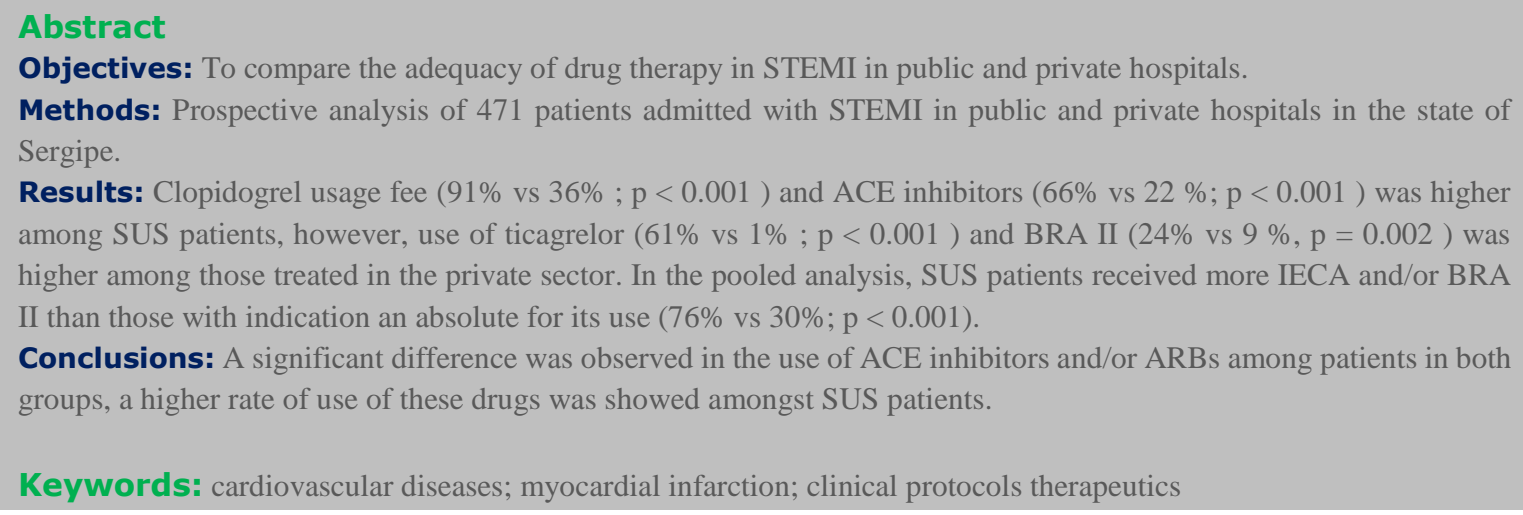

\section{Introduction}

Due to the incidence of Coronary Arterial Death (CAD), it is high in the whole world, and not Brazil, it is the second main cause of death in Brazil and you have indicated that 97 thousand deaths, due to ischemic heart disease, in a year, responsible for 210,046 hospital admissions in Brazil and $29 \%$ two deaths $(99,408$ deaths or 55.11 deaths / 100 thousand inhabitants [9] corresponding to $19 \%$ of total custody with hospital internment, a sum of $\mathrm{R} \$ 1.9$ bilhão [1].

The taxa of morbidity and mortality due to acute myocardial infarction (AMI), not Brazil, are related to the difficulty of not accessing specialized services and lack of attendance and delay in not attending primary care and the elderly is associated with death, in both sexes, besides, older Death taxa, sejam identified in homens [2].

In addition to high mortality from heart attack, analyze two registries of the Swedish Web System for the Development and Development of Care Based on Evidências em Doenças Cardíacas endorsed by agreement with the Registry of Recommended Therapies (SWEDEHEART) will indicate which treatments based on events, as interventions Primary percutaneous coronary arteries (PCI), reperfusion therapies, aspirin, P2Y12 inhibition, beta-blocker, angiotensin-converting enzyme inhibitor / angiotensin 
receptor blocker and statins will collaborate with our results of total and cardiovascular survival [3].

No country is the most populous in the world, a study on AMI management, identified that more than $90 \%$ of these patients were treated with aspirin, clopidogrel and statin, with approximately two patients receiving $\beta$-blockers and / or ACEI / ARB4, but not after discharge, patients who survive, with type I myocardial infarction, derived from acute coronary syndrome, use more aspirin, statin and antiplatelet therapy. [5]

Other important discussions on treatment and therapeutic regimen, address cardiovascular safety of long-term treatment with oral anticoagulant, in this context, a meta-analysis, evidence that anticoagulant escorts, also expose anticoagulated patients to a higher risk of myocardial infarction, and risk of myocardial infarction, and risk of myocardial infarction. , I study or compare some anticoagulants, or risk of heart attack was minor with rivaroxabana6, direct inhibitor of the factor of coagulation Xa.

In addition, we have seen intense efforts in recent years to save on heart attack treatment both during acute hospitalization and secondary prevention in outpatient care. Therefore, despite two significant benefits of pharmacological measures, it is not known that these drugs are prescribed adequately for patients. Therefore, this study aims to compare the adequacy of pharmacological treatment in IAMCSST in public and private hospitals in the state of Sergipe according to the Guideline of ACCF / AHA7 for treatment of IAMCCST.

\section{Materials and Methods}

It deals with a coorte study with a quantitative approach carried out in two hospitals of the public network and three private hospitals of the state of Sergipe with access to angioplasty outside the state of Sergipe, all located in the capital of Aracaju, no period of outubro from 2013 to April 2015. Foram included patients older than 18 years, with STEMI evidenced by electrocardiogram according to the defining criteria of the Guideline of ACCF / AHA7 and that assinaram or TCLE. Foram including patients admitted to two hospitals of the public health network.

It was shown to be composted by 471 patients, since 387 foram cared for in a public health network and 84 in a private network. The data collected by a research group called VICTIM (Via Crucis para o Tratamento do Infrto do Miocardio) composed by doctors, nurses, medicine and pharmacy students and patients will respond to a questionnaire on demographic data, prodromal symptoms and presentation, gatilhos for infarction, premature pathological history, cardiovascular risk factors and previous pharmacotherapy. The clinical data for the collection of hair records two records with information on physical examination of admission, complementary tests, pharmacotherapy used 24 hours and the last prescription before discharge from hospital, plus two hospital injuries.

This investigation was submitted to the Ethics and Research Committee of the Federal University of Sergipe UFS and approved under the number $2,099,430$. All population studied assinou or TCLE, agreeing to participate in the investigation. In cases where the patients are not able to assassinate or thermo, or responsible or fez. Illiterates will be authorized through digital printing, followed by the assumption of two tests.

\section{Result}

Foram included $403(86.62 \%)$ patients admitted to non-public service and $68(14.44 \%)$ non-private, totaling 471 patients with acute myocardial infarction with ST-segment elevation (STEMI). The patients who are users of the public network, were maioria homens (65\%), with lower social class (at least 2 salaries $60 \%$ ), lower grade of schooling (ensino fundamental $49 \%$ ) and who declared themselves to be of non-white ethnicity $(62 \%)$.

\begin{tabular}{|l|c|c|c|}
\hline \multirow{2}{*}{ SOCIODEMOGRAPHIC DICE } & \multicolumn{2}{|c|}{ SERVIÇO } & \multirow{2}{*}{ p-valor } \\
\cline { 2 - 3 } & SUS* $\mathbf{n}(\%)$ & Privado n (\%) & \\
\hline IDADE & $61,45 \pm 12,27$ & $65,88 \pm 13,08$ & 0,023 \\
\hline SEXO & & & 0,059 \\
\hline Mulher & $141(35)$ & $32(47)$ & \\
\hline CLASSE SOCIAL & $262(65)$ & $36(53)$ & \\
\hline$\quad$ I tied 2 minimum wages & $241(60)$ & $7(10)$ & $<0,001$ \\
\hline Between 2 and 20 minimum wages & $106(26)$ & $49(72)$ & \\
\hline More than 20 minimum wages & $1(0,2)$ & $4(6)$ & \\
\hline ESCOLARIDADE & & & \\
\hline I never studied & $122(30)$ & $23(3)$ & \\
\hline Fundamental & $198(49)$ & $17(25)$ & \\
\hline Half & $45(11)$ & $18(26)$ & \\
\hline Higher & $13(3)$ & $4(6)$ & \\
\hline Post-graduation & $2(0,4)$ & & 0,009 \\
\hline ETNIA & & $30(44)$ & \\
\hline Branco & $105(26)$ & $34(50)$ & \\
\hline Não Branco & $250(62)$ & & \\
\hline
\end{tabular}

SUS *: Unique Health System.

Table 1: Socio-demographic characterization among users of the SUS and the private network. 


\begin{tabular}{|c|c|c|c|}
\hline \multirow{2}{*}{$\begin{array}{l}\text { Medicine } \\
\text { (24 h after admission) }\end{array}$} & \multicolumn{2}{|c|}{ SERVIÇO } & \multirow[t]{2}{*}{ p-valor } \\
\hline & SUS* n (\%) & Privado n (\%) & \\
\hline$\overline{\mathbf{A A S}} \boldsymbol{\varphi}$ & $374(94)$ & $63(94)$ & 0,78 \\
\hline Clopidogrel & $362(91)$ & $24(36)$ & $<0,001$ \\
\hline Prasugrel & $0(0)$ & $1(1)$ & 0,145 \\
\hline Ticagrelor & $3(1)$ & $41(61)$ & $<0,001$ \\
\hline Beta-bloqueador & $155(39)$ & $34(51)$ & 0,082 \\
\hline IECA* & $262(66)$ & $15(22)$ & $<0,001$ \\
\hline BRA II§ & $37(9)$ & $16(24)$ & 0,002 \\
\hline Estatina & $317(80)$ & $53(79)$ & 0,87 \\
\hline Bloqueador de cálcio & $21(5)$ & $9(14)$ & 0,025 \\
\hline Nitrato & $92(23)$ & $20(30)$ & 0,28 \\
\hline HBPM// & $228(57)$ & $35(55)$ & 0,50 \\
\hline Heparina convencional & $22(7)$ & $2(3)$ & 0,40 \\
\hline
\end{tabular}

SUS *: Unique Health System; AAS † - Acetylsalicylic Acid; ACEI + - Angiotensin converting enzyme inhibitors; ARB II§- Angiotensin receptor blockers; LMWH // - Low Molecular Weight Heparin

Table 2: Drug therapy used by users of SUS in the private network for the first 24 hours after hospital admission.

Table 2 illustrates the use of medications for the first 24 hours of hospitalization. In a comparison between the patients seen not in the SUS and in the private service, the first ones used Clopidogrel more frequently (91\% vs 36\%; $\mathrm{p}<0.001)$ and ACEI $(66 \%$ vs $22 \%$; $\mathrm{p}<0.001)$. The patients seen in the private service had a comparatively higher prevalence of use of Ticagrelor ( $61 \%$ vs $1 \%$; $\mathrm{p}<0.001)$ and ARB II $(24 \%$ vs $9 \%$; $p=0.002)$.

When the use of beta-blockers is validated in patients who are not contraindicated (Table 3), there is no statistically significant difference between patients in the public service and in the private service. For this analysis, we excluded patients who presented a heart rate without a physical examination of admission below 60 beats per minute, systolic arterial pressure below 100 millimeters of mercury, or Killip> 1.

When using the platelet antiaggregation pair for the first 24 hours of hospitalization (Table 3), expressive taxa of patients who used aspirin (ASA) associated with a platelet antiplatelet is evidenced. Chama atenção also ao fate of $6 \%$ of both the groups (SUS and private) não terem feito use of AAS.

\begin{tabular}{|c|c|c|c|}
\hline \multirow{2}{*}{$\begin{array}{c}\text { Medicine } \\
(24 \mathrm{~h} \text { after admission) }\end{array}$} & \multicolumn{2}{|c|}{ SERVIÇO } & \multirow[t]{2}{*}{ p-valor } \\
\hline & SUS*n $(\%)$ & Privado n (\%) & \\
\hline \multicolumn{4}{|l|}{ Beta-blocker } \\
\hline Sim & $112(46)$ & $26(58)$ & 0,194 \\
\hline $\mathrm{No}$ & $130(54)$ & $19(42)$ & \\
\hline \multicolumn{4}{|c|}{$\begin{array}{l}\text { AAS } \uparrow+\text { Clopidogrel ou AAS + Prassugrel } \\
\text { ou AAS + Ticagrelor }\end{array}$} \\
\hline Sim & $358(90)$ & $64(94)$ & 0,51 \\
\hline $\mathrm{NO}$ & $38(10)$ & $4(6)$ & \\
\hline I do not use AAS & $22(6)$ & $4(6)$ & 0,78 \\
\hline
\end{tabular}

SUS *: Unique Health System; AAS $\uparrow$ - Acetylsalicylic acid.

Table 3: Uso de uso de beta-bloqueadores e dupla antiagregação plaquetária nas primeiras 24 horas de internação pelos usuários do SUS e da rede privada.

Já or use of ACE inhibitors and / or ARBs at the first 24 hours of hospitalization, in patients with previous AMI, ST segment supra-leveling in V3 / V4 evidenced by no ECG, and / or Killip> 1, observed higher taxa of use we attended SUS hair when compared with patients seen in private hospitals (76\% vs 30\%; p <0.001).

\section{Discussion}

Our prospective and observational study of the drug treatment prescribed for the first 24 hours, compared between the public and private hospitals with the capacity to perform primary angioplasty in Sergipe, using data from the VICTIM registry, verified that there was a significant difference in any way. that the patients seen in a private hospital were presented with a mais avançada $(65.88 \pm 13.08$ vs $61.45 \pm 12.27 ; \mathrm{p}=0.023)$.

When comparing the use of drugs in the first 24 hours of care of two patients in the study, it was verified that there was a statistically significant difference in the prescription of antiplatelet drugs. The public service patients had more use of Clopidogrel (91\% vs 36\%; p <0.001), while two private hospitals were prescribed or Ticagrelor (61\% vs 41\%; $\mathrm{p}<0.001)$.

Since I studied CLARITY - Clopidogrel as Adjunctive Reperfusion Therapy $(n=3,491)$, published in 2005 , which validates the importance of associating another antiplatelet antiaggregant to or ASA in patients with STEMI8, or Clopidogrel was or antiaggregant more used, or that it corroborates Given that we are studying when raised in consideration of the patients of the public service. Furthermore, the use of ASA and Clopidogrel was higher in our study than the $87.2 \%$ cited by Bahall et al10, when evaluating or in-hospital treatment of patients with AMI in a country with limited resources

In our study, when the first 24 hours antiaggregation treatment was validated or used, associating the use of ASA with any other antiplatelet 
agent, it was not demonstrated statistically significant difference between the patients attended not in comparison with the private sector. In both groups, there was no record of ASA prescription for the first 24 hours of hospitalization for $6 \%$ of two patients.

Some limitations of the study will end up hampering the analysis of the given. It should be mentioned that there was no question or a research instrument regarding allergy to a drug or other contraindications to its use. Furthermore, patients may have received a recommended initial dose of $200 \mathrm{mg}$ of ASA in the pre-hospital phase, and therefore no record of ASA in the intra-hospital prescription within the first 24 hours or given may have been underestimated.

When I was comparing or general use of two other medications, it was also shown that patients give the public health network in Fez plus use of ACE inhibitors for the first 24 hours $(66 \%$ vs $22 \%$, p <0.001), while no private service was prescribed more ARB $(24 \%$ vs $9 \%, \mathrm{p}=0.002)$. According to the ACCF / AHA Guideline [7], it is recommended to prescribe an ACEI for the first 24 hours in patients with an execution rate of less than $40 \%$. There is evidence that the use of ACE inhibitors in patients reduced the mortality of patients with STEMI by $7 \%$ in 30 days [9]. In cases in which the patients present some contraindication to drugs of this class, it is recommended or use of ARB.

The ACCF / AHA7 guideline also recommends the use of an ACEI / ARB in all patients with STEMI with contraindications for its use, as a recommendation grade IIa and level of evidence A. Also, it is presented as recommendation grade I, level of Evidência A or use of ACEI / ARB in the first 24 hours for all patients with STEMI in the anterior wall, heart failure or failure of execution less than $40 \%$, is not contraindicated. In this way, an analysis was performed as patients who presented anterior AMI hair ECG (ST segment supra-leveling in V3 / V4), or presented Killip> 1 no physical examination of admission. It was not used or criteria for EF $<40 \%$ for most of two cases or an echocardiogram had not been performed within 24 hours. When analyzing or using ACEIs and / or ARBs for the first 24 hours in patients who present some of these indications, I note that I have more use of these medications in patients treated by public service (76\% vs $30 \%$; $p<0.001)$.

It was also observed that the use of beta-blockers in the first 24 hours in patients with contraindications for such. Studies and guidelines [7,9] indicate that oral beta-blocker should be started in the first 24 hours in patients with STEMI who do not present two following criteria: no heart failure, evidence of low-output state, increased risk for cardiogenic shock, or other Contraindication for its use (PR interval greater than 0.24 seconds, cardiac block of second or third grau, active asthma or effective dose of airways). There are limitations to the evaluation of all the contraindications to the use of beta-blockers that are not an instrument of the research group. Therefore, we selected the patients whose physical examination gives admission to present $\mathrm{HR}>60, \mathrm{BP}>100$ and Killip $=1$. Furthermore, there is no statistically significant difference from this analysis.

\section{Conclusions}

When it comes to intra-hospital pharmacological treatment of STEMI, the public health network appears to be a better tax on the use of ACEI / ARB in relation to the private sector, drug classes that are important in the acute phase of this condition. However, both present a reduced taxa for the use of some medications as an indication of use for the first 24 hours postAMI second or more recent guideline from ACCF / AHA, published in 2013, showing that there is space for no in-hospital pharmacological treatment. do IAMCSST not state of Sergipe.

\section{References}

1. Smanio, P. E. P., Silva, J. H., Holtz, J. V., Ueda, L., Abreu, M., Marques, C., \& Machado, L. (2015). Myocardial scintigraphy in the evaluation of cardiac events in patients without typical symptoms. Arquivos brasileiros de cardiologia, 105, 112-122.

2. Santos, J. D., Meira, K. C., Camacho, A. R., Salvador, P. T. C. D. O., Guimarães, R. M., Pierin, Â. M. G., ... \& Freire, F. H. M. D. A. (2018). Mortalidade por infarto agudo do miocárdio no Brasil e suas regiões geográficas: análise do efeito da idadeperíodo-coorte. Ciência \& Saúde Coletiva, 23, 1621-1634

3. Szummer, K., Wallentin, L., Lindhagen, L., Alfredsson, J., Erlinge, D., Held, C., ... \& Jernberg, T. (2017). Improved outcomes in patients with ST-elevation myocardial infarction during the last 20 years are related to implementation of evidence-based treatments: experiences from the SWEDEHEART registry 1995-2014. European heart journal, 38(41), 3056-3065.

4. Wang, L., Zhou, Y., Qian, C., \& Wang, Y. (2017). Clinical characteristics and improvement of the guideline-based management of acute myocardial infarction in China: a national retrospective analysis. Oncotarget, 8(28), 46540.

5. Smilowitz, N. R., Subramanyam, P., Gianos, E., Reynolds, H. R., Shah, B., \& Sedlis, S. P. (2018). Treatment and Outcomes of Type 2 Myocardial Infarction and Myocardial Injury Compared to Type 1 Myocardial Infarction. Coronary artery disease, 29(1), 46

6. Kupó, P., Szakács, Z., Solymár, M., Habon, T., Czopf, L., Hategan, L., ... \& Komócsi, A. (2020). Direct anticoagulants and risk of myocardial infarction, a multiple treatment network meta-analysis. Angiology, 71(1), 27-37.

7. Collet JP, Thiele H, et al. ESC Diretrizes para o manejo de síndromes coronárias agudas em pacientes que apresentam sem elevação persistente do segmento ST. Eur Heart J 2020. doi/10.1093/eurheartj/ehaa575

8. Sabatine MS, Cannon CP, Gibson CM, López-Sendón JL, Montalescot G, Theroux $\mathrm{P}$ et al., CLARITY-TIMI 28 Investigators. Addition of clopidogrel to aspirin and fibrinolytic therapy for myocardial infarction with ST-segment elevation. N. Engl. J. Med. 2005; 352:1179-1189. DOI: 10.1056/NEJMoa050522.53

9. Bahit MC, Kochar A, Granger CB. Post-Myocardial Infarction Heart Failure. JACC Heart Fail. 2018 Mar;6(3):179-186. doi: 10.1016/j.jchf.2017.09.015. PMID: 29496021.

10. Bahall, M., Seemungal, T., Khan, K. et al. Medical care of acute myocardial infarction patients in a resource limiting country, Trinidad: a cross-sectional retrospective study. BMC Health Serv Res 19, 501 (2019). 
(cc) (i)

This work is licensed under Creative Commons Attribution 4.0 License

To Submit Your Article Click Here: Submit Manuscript

DOI: $10.31579 / 2641-0419 / 205$
Ready to submit your research? Choose Auctores and benefit from:

* fast, convenient online submission

* rigorous peer review by experienced research in your field

* rapid publication on acceptance

* authors retain copyrights

* unique DOI for all articles

* immediate, unrestricted online access

At Auctores, research is always in progress.

Learn more auctoresonline.org/journals/journal-of-surgical-case-reportsand-images 